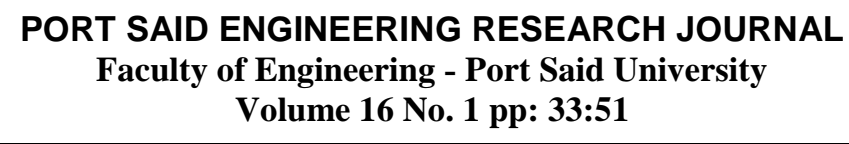

\title{
EFFECT OF IMPARTING SWIRL MOTION TO FUEL SPRAY AND COMBUSTION AIR STREAMS ON THERMAL FLAME CHARACTERISTICS
}

\author{
ALY KAMEL ABD EL-SAMED \\ Mechanical Power Engineering Department, Faculty of Engineering, \\ Port-Said University \\ Port-Said, Egypt
}

\begin{abstract}
The effect of imparting swirl motion to the fuel spray and combustion air streams on thermal flame characteristics is experimentally investigated using a horizontal water cooled combustor. A pressure swirl atomizer with a narrow nozzle of $0.4 \mathrm{~mm}$ diameter is used. To impart swirling motion to the fuel spray, the atomizer spin chamber is designed to have four tangent-perpendicular passages. Also, to possess swirling motion to the combustion air, the hub diameter ratio and the vanes angle of the combustion air swirler are changed leading to a change of the air swirl number. Both of the fuel and combustion air streams are co-swirled keeping the air-fuel ratio constant at 19 for the seventeen runs. Very stable flames are formed. Gas temperature distributions are measured along the combustor. Overall heat transfer rate to the combustor wall are determined. The highest heat flux value $67.7 \mathrm{~kJ} / \mathrm{m}^{2} . \mathrm{s}$ is obtained by combining the best designed parameters of the spin chamber and combustion air swirler.
\end{abstract}

KEY WORDS: spray, spin chamber, swirling motion, flames stability, heat flux

\section{INTRODUCTION}

Experience has shown that with the pressure type atomizer, combustion at high pressure is characterized by most soot formation in the primary burning zone leading to problems of carbon deposition and excessive exhaust smoke. So, good mixing process of the fuel and combustion air leads to an improvement of the combustion process [1] The effects of imparting swirl to the combustion air stream were reported [2-5]. The interaction of complex physical and chemical processes in the combustion of fuel sprays was discussed in [6-10]. The effect of droplet size and spatial distribution on flame structure, gas flow pattern and temperature distribution were reported in [11-18]. The momentum of air and the fuel streams have a great effect on mixing rate [19], flame stability [20-22] and combustion intensity [23-25]. An experimental investigation was carried out to study the effect of fuel nozzle displacement on the structure of a spray [26]. Also, the blowout process and mechanism of diffusion flames were investigated [27-30].

In the present work, the effect of changing: (A) the diameter and depth of the atomizer spin chamber, and (B) the hub diameter and vanes angle of the combustion air swirler; on: the value of the spray cone angle, vanish of the exhaust soot and the thermal flame characteristics are investigated. Each of the above four parameters is changed in turn, keeping the other three parameters constant. Throughout seventeen experimental runs, the thermal flame characteristics are presented and discussed through:

1. Gas temperature distributions,

2. Overall heat transfer to the combustor wall,

3. Confined visual flame length, and

4. Lean blowout limits.

\section{EXPERIMENTAL ARRANGEMENT}

Schematic diagram of the experimental apparatus is shown in Fig.1. It is mainly composed of; a water cooled combustor, a fuel system and a combustion air system.

The combustor (10) is a horizontal tube with $32 \mathrm{~cm}$ inner diameter and $150 \mathrm{~cm}$ length. It is equipped with 17 tapping holes of $16 \mathrm{~mm}$ diameter arranged in line along the combustor wall. The first seven holes 5 $\mathrm{cm}$ apart but the other ten holes are $10 \mathrm{~cm}$ apart. Through these holes, the measuring probes are introduced. The combustor tube is surrounded by cooling-water jacket (15) and covered with a thermal insulation (16).

The fuel system consists of a tank (1), a filter, a gear pump (3) driven by $2 \mathrm{~kW}$ electric motor, a pressure gauge (5) and the pressure swirl atomizer (14). To achieve spray formation, the Kerosene fuel was pressurized inside the atomizer up to a pressure of 12.5 bar and then discharged with constant flow rate of 12.6 $\mathrm{kg} / \mathrm{h}$ through a narrow orifice (nozzle) of $0.4 \mathrm{~mm}$ diameter and $1.0 \mathrm{~mm}$ length. To obtain swirled-finer spray droplets, a special spin chamber is designed and installed. The construction design parameters of the spin chambers (group A-1 and group A-2) are shown in Fig.2a. Each spin chamber has four grooved passages with constant depth of $1.0 \mathrm{~mm}$ and constant width of 0.5 $\mathrm{mm}$. The four passages are tangent to the inner surface of the spin chamber and perpendicular to each other. These passages create the swirling motion of the fuel inside the spin chamber and impart to the fuel a high angular velocity. The sectional drawing of the pressure swirl atomizer is shown in Fig.2b. It was noticed from the preliminary runs, that both of the inner diameter and 
the depth of the spin chamber affect strongly the spray cone angle of the fuel swirl. Two groups based on changing the spin chamber geometry were formed; group A-1 was concerned with the effect of changing the inner diameter of the spin chamber $\left(d_{s}\right)$ which is ranged from 3 to $5,7,9,10.5$ and $12 \mathrm{~mm}$ keeping the spin chamber depth constant at $4 \mathrm{~mm}$. Group A-2 was concerned with the effect of changing the spin chamber depth $\left(\mathrm{L}_{\mathrm{s}}\right)$ from 4 to 7, 9.3 and $12 \mathrm{~mm}$ keeping the spin chamber diameter constant at $7 \mathrm{~mm}$.

The combustion air was emerged from a blower (6), driven by $3 \mathrm{~kW}$ electric motor, with a constant flow rate of $240 \mathrm{~kg} / \mathrm{h}$. therefore, the air-fuel ratio is kept constant at 19 for all runs. Eight combustion air swirlers were used in the present investigation. Another two groups (group B-1 and group B-2) based on changing the air swirler geometry were formed. Group B-1, was concerned with changing the vanes angle of the combustion air swirler from $30^{\circ}$, to $45^{\circ}$, and $60^{\circ}$ keeping the hub diameter of $34 \mathrm{~mm}$ and the outer diameter of $77 \mathrm{~mm}$ constant. The corresponding calculated $\mathrm{SN}$ for these swirlers were $0.44,0.76$ and 1.31 respectively. While group B-2, was concerned with changing the hub diameter $\left(d_{h}\right)$ from 34 to $40,46,51,57$ and $62 \mathrm{~mm}$ keeping both of the vanes angle and outer swirler diameter constant at $30^{\circ}$ and $77 \mathrm{~mm}$ respectively. So, the corresponding hub diameter ratio (= hub diameter/outer diameter) were $0.44,0.52,0.60$, $0.66,0.74$ and 0.81 also the corresponding swirl numbers (SN) were $0.44,0.45,0.47,0.49,0.51$ and 0.52 respectively. The air swirl number $(\mathrm{SN})$ was calculated based on Beer and Chigier's relation [31]. The geometrical design parameters of Group B-1 and Group B-2 of the combustion air swirler are shown in Fig.3.

Gas temperatures were measured using $100 \mu$ bare thermocouples wires (Pt \& Pt-Rh $13 \%$ ). The wires had a fork-shape with very fine head in the middle of the supporting wires span (16). The gas temperatures were measured along a half of the combustor tube through the 17 holes which drilled along the combustor tube- in the radial direction at incremental distance of 1 $\mathrm{cm}$. Sectional average gas temperature was calculated at every hole level by dividing the cross sectional area of the combustor tube into 16 annular area as shown in the fig. (a), then applying the following equation;

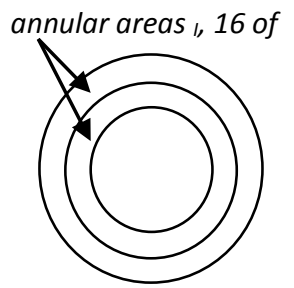

Fig. (a) combustor cross section
Section average gas temperature $=$

$$
\sum_{i=1}^{i=16} t_{i} \times \text { annulararea }_{i}
$$

cross sectional area of the combustor tube

where, $t_{i}=$ average incremental temperatures of the two boundaries of the annular area . $_{\text {. }}$

The lean blow-out limits were determined by setting the combustion airflow rate at a certain level, and a blow out sequence obtained by reducing the fuel rate until the flame extinguished. Ignition is again established and a new airflow rate is selected and blow out is again obtained. This procedure was repeated until a maximum airflow condition was reached.

The flame end was determined visually through the measuring holes and then the flame length was measured using a scaled ruler.

The overall flux of heat transferred to the combustor wall was calculated by measuring the heat gained by the insulated cooling water jacket via measuring the inlet and outlet temperatures for a certain cooling water flow rate using insulated Chromel/Alumel thermocouples (18).

Overall Heat Flux $=$

$$
\boldsymbol{m}_{c . w .} \times C_{p c . w .} \times \Delta t_{c . w}
$$

inner surface area of the combustor tube

The developed spray cone angles were measured directly using a big $180^{\circ}$ angle and $30 \mathrm{~cm}$ in diameter protractor. Two 1000 watt electric flashes were used to focus intensive light on the spray. Values of cone angles were checked and emphasized with the photographs of the spray from two sides of the atomizer using a digital power shot camera -(Canon S10). The shape of the spray distribution was clearly viewed and the spray cone angle was measured. The cone angle is denoted as the angle formed by two straight lines drawn from the discharge orifice to tangent the outermost spray contours at some specified distance from the atomizer face.

The suitable operating conditions for all the experimental test runs- such as, atomizing fuel pressure, fuel flow rate, combustion air flow rate and co-swirl streams- were chosen after several preliminary trials. Run-3 was chosen to be a common case with the all groups. This is because it produces a smoky and unstable flame accompanied the least heat transfer to the combustor wall and also the least gas temperature distributions. Therefore, effects of changing the depths of the spin chamber, the air swirler hub diameters ratios and the air swirl numbers to improve the combustion process could be noticeable and clear. The program of the schedule experimental runs is shown in Table-1 as follows: 
Table-1

The schedule of the experimental runs

Group A-1, Changing the diameter of the spin chamber, $\left(d_{s}\right)$

\begin{tabular}{|c|c|c|c|c|c|c|c|}
\hline & \multicolumn{2}{|c|}{ Fuel Spin Chamber } & \multicolumn{3}{c|}{ Combustion Air Swirler } \\
\cline { 2 - 8 } Run No. & $\begin{array}{c}\text { Diameter } \\
\text { of the } \\
\text { spin } \\
\text { chamber, } \\
\left(\mathrm{d}_{\mathrm{s}}\right) \mathrm{mm}\end{array}$ & $\begin{array}{c}\text { Depth of } \\
\text { the spin } \\
\text { chamber, } \\
\left(\mathrm{L}_{\mathrm{s}}\right) \mathrm{mm}\end{array}$ & $\begin{array}{c}\text { Spin } \\
\text { chamber } \\
\text { ratio }\end{array}$ & $\begin{array}{c}\text { Angle } \\
\text { of air } \\
\text { swirler } \\
\alpha\end{array}$ & $\begin{array}{c}\text { Air Swirl } \\
\text { Number } \\
(\mathrm{SN})\end{array}$ & $\begin{array}{c}\text { Hub } \\
\text { diameter } \\
\left(\mathrm{d}_{\mathrm{h}}\right), \mathrm{mm}\end{array}$ & $\begin{array}{c}\text { Hub } \\
\text { diameter } \\
\text { ratio of } \\
\text { air } \\
\text { swirler }\end{array}$ \\
\hline Run-1 & $\mathbf{3}$ & 4 & 0.75 & $30^{\circ}$ & 0.44 & 34 & 0.44 \\
\hline Run-2 & $\mathbf{5}$ & 4 & 1.25 & $30^{\circ}$ & 0.44 & 34 & 0.44 \\
\hline Run-3 & $\mathbf{7}$ & 4 & 1.75 & $30^{\circ}$ & 0.44 & 34 & 0.44 \\
\hline Run-4 & $\mathbf{9}$ & 4 & 2.25 & $30^{\circ}$ & 0.44 & 34 & 0.44 \\
\hline Run-5 & $\mathbf{1 0 . 5}$ & 4 & 2.63 & $30^{\circ}$ & 0.44 & 34 & 0.44 \\
\hline Run-6 & $\mathbf{1 2}$ & 4 & 3.00 & $30^{\circ}$ & 0.44 & 34 & 0.44 \\
\hline
\end{tabular}

Group A-2, Changing the depth of the spin chamber, $\left(L_{s}\right)$

\begin{tabular}{|c|c|c|c|c|c|c|c|}
\hline Run-3 & 7 & $\mathbf{4}$ & 1.75 & $30^{\circ}$ & 0.44 & 34 & 0.44 \\
\hline Run-7 & 7 & $\mathbf{7}$ & 1.00 & $30^{\circ}$ & 0.44 & 34 & 0.44 \\
\hline Run-8 & 7 & $\mathbf{9 . 3}$ & 0.75 & $30^{\circ}$ & 0.44 & 34 & 0.44 \\
\hline Run-9 & 7 & $\mathbf{1 2}$ & 0.58 & $30^{\circ}$ & 0.44 & 34 & 0.44 \\
\hline
\end{tabular}

Group B-1, Changing the vanes angle of the combustion air swirler, $(\alpha)$

\begin{tabular}{|c|c|c|c|c|c|c|c|}
\hline Run-3 & 7 & 4 & $\mathbf{1 . 7 5}$ & $\mathbf{3 0}^{\boldsymbol{0}}$ & $\mathbf{0 . 4 4}$ & 34 & 0.44 \\
\hline Run-10 & 7 & 4 & $\mathbf{1 . 7 5}$ & $\mathbf{4 5}^{\mathbf{0}}$ & $\mathbf{0 . 7 6}$ & 34 & 0.44 \\
\hline Run-11 & 7 & 4 & $\mathbf{1 . 7 5}$ & $\mathbf{6 0}^{\boldsymbol{0}}$ & $\mathbf{1 . 3 1}$ & 34 & 0.44 \\
\hline
\end{tabular}

Group B-2, Changing the hub diameter of the combustion air swirler, $\left(d_{h}\right)$

\begin{tabular}{|c|c|c|c|c|c|c|c|}
\hline Run-3 & 7 & 4 & 1.75 & $30^{\circ}$ & $\mathbf{0 . 4 4}$ & $\mathbf{3 4}$ & $\mathbf{0 . 4 4}$ \\
\hline Run-12 & $\mathbf{7}$ & 4 & 1.75 & $30^{\circ}$ & $\mathbf{0 . 4 5}$ & $\mathbf{4 0}$ & $\mathbf{0 . 5 2}$ \\
\hline Run-13 & $\mathbf{7}$ & 4 & 1.75 & $30^{\circ}$ & $\mathbf{0 . 4 7}$ & $\mathbf{4 6}$ & $\mathbf{0 . 6 0}$ \\
\hline Run-14 & $\mathbf{7}$ & 4 & 1.75 & $30^{\circ}$ & $\mathbf{0 . 4 9}$ & $\mathbf{5 1}$ & $\mathbf{0 . 6 6}$ \\
\hline Run-15 & 7 & 4 & 1.75 & $30^{\circ}$ & $\mathbf{0 . 5 1}$ & $\mathbf{5 7}$ & $\mathbf{0 . 7 4}$ \\
\hline Run-16 & 7 & 4 & 1.75 & $30^{\circ}$ & $\mathbf{0 . 5 2}$ & $\mathbf{6 2}$ & $\mathbf{0 . 8 1}$ \\
\hline
\end{tabular}

Combination of the Best Designed Parameters of the Spin Chamber and Combustion Air Swirler

\begin{tabular}{|l|l|l|l|l|l|l|l|} 
Run-17 & 7 & 9.3 & 0.75 & $45^{\circ}$ & 0.84 & 51 & 0.66 \\
\hline
\end{tabular}




\section{RESULTS AND DISCUSSION}

As the atomizer fuel pressure increased gradually, it began to discharge from the atomizer nozzle in the form of a solid jet then it twisted and formed cork-screw with insufficient swirl velocity to produce an air core. As the injection pressure increased the jet began to break up and the developed hollow-cone spray formed. These stages were visualized clearly with the help of 1000 watt flashes. Similar results were obtained [32 and 33]. Using air swirler which creates vortex motions inside the combustor, a central recirculation zone was formed. This increases turbulence and mixing rate of fuel and air streams. When combustion was occurred, the reversed hot combustion products heat-up the fresh mixture and stable flame was formed and high chemical reaction rate zone was recorded upstream, referring to the highest gas temperatures in that zone. The radial gas temperature was reduced as moving towards the combustor wall.

The local gas temperatures were measured in both radial and axial directions at 289 points along and across the half of the combustor tube. Then, maps (contours) and sectional average gas temperatures were drawn for all the runs of the different operating conditions assuming axi-symmetric measurements along the combustor. The maximum recorded gas temperature value of $1280^{\circ} \mathrm{C}$ was found corresponding to Run-2, at dimensionless axial distance $\mathrm{x} / \mathrm{L}=0.08-0.12$ and at dimensionless radial distance $\mathrm{r} / \mathrm{R}=0.6-0.8$. It seems that the maximum temperature (i.e the maximum reaction rate) can be attributed to the effect of high evaporation and mixing rates, which corresponds to the spray cone angle $76^{\circ}$.

\subsection{Flame Stability}

Flame stability is described in terms of blowout and stable flame. The blow-out means stop flame burning by blowing air at the flame. Stable flame means the flame properties are continuously steady. The two conditions, which are the blowout and the stable flames limits for the 16 runs are displayed in Fig.4. These curves are found to be close to each other and all of them have the same trend. As the fuel flow rate increased from 0.36 to $0.5 \mathrm{~kg} / \mathrm{h}$, the sustainable air flow rate increased sharply from 72 to $162 \mathrm{~kg} / \mathrm{h}$ and the corresponding air/fuel ratios became 200 and 324 respectively. Further increase in the fuel flow rate, increases the sustainable air flow rate very slightly (as can be seen from the slight change of the slope of the curve), until the air/fuel ratio reduced to 87 at fuel flow rate $2.15 \mathrm{~kg} / \mathrm{h}$. These values of the air/fuel ratio are exceeding the limits of many practical combustion applications. That means, the designed burning system produces more stable flames for a wide range of different operating conditions.

\subsection{Effect of Changing the Diameter of the Spin Chamber, $d_{s}$ (i.e.Group A-1)}

As the spin chamber diameter increased from 3 to $5,7,9,10.5$, and $12 \mathrm{~mm}$ keeping the depth of the spin chamber constant at $4 \mathrm{~mm}$; the corresponding spray cone angles were found to be $98^{\circ}, 75^{\circ}, 36^{\circ}, 62^{\circ}, 66^{\circ}$, and $75^{\circ}$, respectively. These cone angles were measured by the protractor and emphasized from the photographs of the spray cone angles, which are shown in Fig.5 and presented as values in Fig.6. The widest fuel spray cone angle of this group was $98^{\circ}$, which corresponding to spin chamber diameter $3 \mathrm{~mm}$ (Run-1). For the widest angle, the spray had more opportunity for faster evaporation rate and consequently faster mixing rate with the combustion air leading to the shortest flame length of $55 \mathrm{~cm}$. But the maximum flame length of 150 $\mathrm{cm}$ corresponds to spin chamber diameter $7 \mathrm{~mm}$, i.e. spray cone angle $36^{\circ}$ (Run-3). The confined flame length was found to be changed remarkably with the change of the spin chamber diameter as presented in Fig.6. In general, the obtainable confined flames of these runs were stable with golden colour except the flame of Run-3 (spin chamber diameter of $7 \mathrm{~mm}$ ) which accompanied with a lot of soot.

Gas temperature distributions were found to be affected too much by the change of the spin chamber diameter as shown from the gas temperatures contours in Fig.7. For spin chamber diameter $3 \mathrm{~mm}$ (Run-1) it can be noticed that the high reaction rate zone (i.e. the highest gas temperature zone) was found around the axis of the combustor at $\mathrm{r} / \mathrm{R}=0.2-0.95$, and $\mathrm{x} / \mathrm{L}=0.033$ 0.4 . In other words, it extended in a large volume, beginning very close to the atomizer exit, and extended to the middle of the combustor. As the spin chamber diameter increased from 3 to 5 and $7 \mathrm{~mm}$, the high reaction rate zone was shrinked and occupied a smaller volume and moved inwards toward the combustor axis closer to the atomizer exit. Consequently, the corresponding sectional average gas temperature along the combustor decreased and its value at the combustor exit was $750^{\circ} \mathrm{C}, 600^{\circ} \mathrm{C}$ and $580^{\circ} \mathrm{C}$, respectively as shown in Fig.8. More increase of the spin chamber diameter to $9,10.5$ and $12 \mathrm{~mm}$ caused a displacement of the high reaction rate zone outward toward the combustor wall. Consequently, the corresponding sectional average gas temperature at combustor exit increased and then decreased as $740^{\circ} \mathrm{C}, 705^{\circ} \mathrm{C}$, and $665^{\circ} \mathrm{C}$, respectively. It is noticed from the figure that the general trend of the sectional average gas temperature along the combustor- increased gradually up to higher reaction rate zones upstream and then decayed smoothly downstream where the reaction ended.

The maximum heat flux value of $57.2 \mathrm{~kJ} / \mathrm{m}^{2} . s$ was found to be for spin chamber diameter $3 \mathrm{~mm}$, Run1 (i.e. spin chamber ratio $=0.75$, and maximum spray cone angle of $98^{\circ}$ ). The minimum value of $53.72 \mathrm{~kJ} / \mathrm{m}^{2} . s$ corresponded to spin chamber diameter $7 \mathrm{~mm}$, Run-3 (i.e. spin chamber ratio $=1.75$, and minimum spray cone angle of $36^{\circ}$ ) as presented in Fig.9.

\subsection{Effect of Changing the Depth of the Spin Chamber, Ls (i.e. Group A-2)}

As the depth of the fuel spin chamber was changed from 4 to $7,9.3$ and $12 \mathrm{~mm}$, keeping the chamber diameter constant at $7 \mathrm{~mm}$, the measured spray cone angles corresponding to the above depths were found to be $36^{\circ}, 64^{\circ}, 76^{\circ}$ and $54^{\circ}$, respectively, as shown from the photographs in Fig.10 then presented as values 
in Fig.11. From Fig.11 it can be noticed that, the flame length decreased as the spray cone angle increased, and vice versa. The largest cone angle and consequently the expected highest fuel evaporation rate was confirmed to be for spin chamber depth $9.3 \mathrm{~mm}$, Run-8, and the obtained flame in this case was found to be wrinkled, golden colour, wide and covers most of the radialupstream section of the combustor. More increase in chamber depth leads to a poor quality of combustion. The flame of $12 \mathrm{~mm}$ spin chamber depth, Run-9, was found to be orange-black colour accompanied with soot at exhaust section and it was smooth in shape, long, narrow and the flame itself convoluted in the form of a flying cylinder around the combustor axis.

As the spin chamber depth was increased from 4 to 7 and $9.3 \mathrm{~mm}$, the highest gas temperatures zone, which referred as the highest reaction rate zone, was displaced away from the combustor axis and moves towards the combustor wall. Further increase in the depth up to $12 \mathrm{~mm}$, the high reaction rate zone was returned back to its place around the combustor axis and closer to the atomizer exit as shown from Fig.12. The highest gas temperature of $1272^{\circ} \mathrm{C}$ was recorded for spin chamber depth $9.3 \mathrm{~mm}$, Run-8, at $\mathrm{r} / \mathrm{R}=0.75$ and $\mathrm{x} / \mathrm{L}=0.133$ as shown in Fig.12. Also, the highest sectional average gas temperatures along the combustor were found for spin chamber depth $9.3 \mathrm{~mm}$ as shown in Fig. 13, and its peak value was $823^{\circ} \mathrm{C}$.

Changing the spin chamber depth had a great effect on the heat transfer to the combustor wall. As the depth changed from 4 to $9.3 \mathrm{~mm}$, the near wall gas temperatures were found to be increased, consequently, the heat flux value increased from 53.72 to 62.32 $\mathrm{kJ} / \mathrm{m}^{2} . s$., as presented in Fig. 14 . The maximum values of gas temperatures along the combustor are found to be for spin chamber depth $9.3 \mathrm{~mm}$, Run-8 (i.e. with spin chamber ratio $=0.75$ and spray cone angle of $76^{\circ}$ ). Further increase of the depth leads to a reduction of the heat flux value to be $54.375 \mathrm{~kJ} / \mathrm{m}^{2}$.s., as shown in Fig.14,. It was noticed from Fig.13 and Fig.14, that there is a coincidence order of the mean sectional average gas temperature with that of heat flux value.

\subsection{Effect of Changing the Vanes Angle of the Combustion Air Swirler $(\alpha)$, (i.e. Group B-1)}

As the combustion air swirl angle increased from $30^{\circ}$ (Run-3) to $45^{\circ}$ (Run-10) and 60 (Run-11), the swirl number (SN) extremely increased from 0.44 to 0.76 and 1.31 , respectively. So, the discussion will be based on the swirl number ( $\mathrm{SN}$ ) rather than swirl angle. Consequently, the rotational momentum imparted to the flow increased leading to a reduction in flame length from 150 to 85 and $75 \mathrm{~cm}$, respectively, as presented in Fig.15. Also, the high reaction rate zone moved towards the combustor wall and displaced downstream as shown from Fig.16. As the swirl number increased from 0.44 to 0.76 , the sectional average gas temperatures along the combustor increased remarkably and the corresponding exit gas temperature increased from $584^{\circ} \mathrm{C}$ to $830^{\circ} \mathrm{C}$ as shown in Fig.17. Further increase of SN from 0.76 to 1.31 leads to a slight reduction of the sectional average gas temperatures along the combustor and also the exit gas temperature decreased from $830^{\circ} \mathrm{C}$ to $813^{\circ} \mathrm{C}$. That is reflected in the heat transfer values to the combustor wall, where the heat flux increased and then decreased as SN increased, and their corresponding values were $53.72,57.57$ and $56,945 \mathrm{~kJ} / \mathrm{m}^{2}$.s respectively, as shown in Fig.18. The maximum sectional average gas temperatures and the maximum heat transfer flux was found to be for air swirl angle $45^{\circ}$ (i.e. $\mathrm{SN}=0.76$ and hub diameter ratio 0.44), Run-10.

\subsection{Effect of Changing the Hub Diameter of the Combustion Air Swirler $\left(d_{h}\right)$, (i.e. Group B-2)}

As the air swirler hub diameter $\left(\mathrm{d}_{\mathrm{h}}\right)$ increased from 34 to $40,46,51,57$ and $62 \mathrm{~mm}$ the hub diameter ratio ( $=$ hub diameter/outer diameter) increased from 0.44 to $0.52,0.60,0.66,0.74$ and 0.81 consequently, the corresponding swirl number (SN) increased slightly from 0.44 to $0.45, \quad 0.47, \quad 0.49, \quad 0.51$ and 0.52 respectively. The obtained flame length was nearly constant at $150 \mathrm{~cm}$ except for HDR $=0.81$, at which the flame length decreased sharply to $85 \mathrm{~cm}$ as shown in Fig.19. As the hub diameter ratio increases, the highest reaction rate zone shifted slightly towards the combustor wall and extending to cover a larger area of the combustor up to hub diameter ratio $=0.74$ then it shrinks at the ratio of 0.81 as shown in Fig.20. As the hub diameter ratio increased from 0.44 to 0.52 (i.e. slight increase of the corresponding swirl number from 0.44 to 0.45 ), it was noticed from Fig.21 that the average gas temperatures along the combustor increased remarkably by about $150^{\circ} \mathrm{C}$ and the sectional average gas temperatures at exit section also increased from $584^{\circ} \mathrm{C}$ to $742^{\circ} \mathrm{C}$. This indicates that, the increase of HDR is more effective and should be taken into consideration rather than the slight corresponding increase of SN. As a result of that increase, the gas temperature values and consequently heat transfer to the combustor wall increased from 53.5 to $57.2 \mathrm{~kJ} / \mathrm{m}^{2}$.s. as presented in Fig.22. Further increase of HDR up to 0.81, lead to a slight fluctuation of the gas temperature values, vanish of the soot exhausted from the combustor end, change of the flame colour from orange into golden and fluctuation of the heat transfer values to the combustor wall. So for the running group, it is recommend proceed combustion process at swirl number (SN) and hub diameter ratio (HDR) not less than 0.45 and 0.52 respectively. From the above context it is noticed that, the most effective parameter on the thermal flame characteristics is HDR rather than the corresponding value of $\mathrm{SN}$. The maximum heat flux value of 58.76 $\mathrm{kJ} / \mathrm{m}^{2} . s$ was found to be for hub diameter ratio 0.66 (i.e. $\mathrm{SN}=0.49$ ) and $\mathrm{SCR}=1.75$, Run-14, as shown in Fig.22.

\subsection{Combination of the Best Designed Parameters of the Spin Chamber and Combustion Air Swirler}

From the above operating runs, a combination of the best designed parameters of the atomizer spin 
chamber and combustion air swirler were selected and tested. The highest heat flux value $67.7 \mathrm{~kJ} / \mathrm{m}^{2}$.s.was obtained from spin chamber ratio of 0.75 , combined with the combustion air vanes angle of $45^{\circ}$ and hub diameter ratio of 0.66 (i.e. $\mathrm{SN}=0.84$ ), Run-17.

\section{CONCLUSIONS}

1. The obtainable flames of the designed burner are very stable for the different operating conditions.

2. The obtainable spray cone angle ranged from $36^{\circ}$ to $98^{\circ}$. It changes remarkably as the atomizer spin chamber ratio (diameter/depth) changes. As the spray cone angle increases the obtainable flame length decreases.

3. The maximum value of the gas temperature and consequently the maximum value of the heat flux to the combustor wall are found to be 57.2, 62.32, 57.57, and 58.76, $\mathrm{kw} / \mathrm{m}^{2}$. corresponding to the best run of each of the four running groups as follows respectively:

a) Run-1; spin chamber ratio of the atomizer 0.75 , and spray cone angle $98^{\circ}$.

b) Run-8; spin chamber ratio of the atomizer 0.75 (also), and spray cone angle $76^{\circ}$.

c) Run-10; vanes angle of the combustion air swirler $45^{\circ}$ (i.e. air swirl number 0.76).

d) Run-14; hub diameter ratio of the combustion air swirler 0.66 (i.e. air swirl number 0.49).

4. It is more convenient for the combustion researches to apply the value of the hub diameter ratio and the vanes angle of the combustion air swirler separately instead of related them together as swirl number.

5. The highest heat flux value $67.7 \mathrm{~kJ} / \mathrm{m}^{2} . \mathrm{s}$ is obtained by combining the best designed parameters of the atomizer spin chamber and combustion air swirler. The values of these combined parameters are: atomizer spin chamber ratio of 0.75 (i.e. moderate spray cone angle $=76^{\circ}$ ), combustion air vanes angle of $45^{\circ}$ and hub diameter ratio of 0.66 (i.e. combustion air swirl number $=0.84$, Run-17).

\section{NOMENCLATURE:}

$\alpha=$ Angle of the air swirler, degree

$\mathrm{d}_{\mathrm{h}}=$ Hub diameter of the air swirler, $\mathrm{mm}$

$\mathrm{d}_{\mathrm{s}}=$ Diameter of the spin chamber, $\mathrm{mm}$

$\mathrm{r}=$ certain radial distance, $\mathrm{cm}$

$\mathrm{R}=$ radius of the combustor tube, $\mathrm{cm}$

$\mathrm{R}_{\mathrm{h}}=$ Hub radius of the air swirler, $\mathrm{mm}$

$\mathrm{R}_{\text {out }}=$ Outer diameter of the air swirler, $\mathrm{mm}$

$\mathrm{L}=$ Length of the combustor tube, $\mathrm{cm}$

$\mathrm{L}_{\mathrm{s}}=$ Depth of the spin chamber, $\mathrm{mm}$

$\mathrm{SN}=$ Swirl number,

$\mathrm{x}=$ certain axial distance, $\mathrm{cm}$

$m_{c . w .}=$ mass flow rate of the cooling water, $\mathrm{kg} / \mathrm{s}$

$\mathrm{C}_{\mathrm{pcw}}=$ specific heat of the cooling water, $\mathrm{kJ} / \mathrm{kg} . \mathrm{K}$
$\Delta t_{\text {c.w. }}=$ temperature difference of the cooling water, $\mathrm{K}$. Spin chamber ratio, $\mathrm{SCR}=$ spin diameter $/$ spin depth Hub diameter ratio, HDR $=$ hub diameter $/$ outer diameter

\section{REFERANCES}

[1] Timothy R., Frazier, Robert E. Fogle Song, Robert E. Coverdill, James E. Peters, Robert P. Lucht, Illinois University At Urbana, Dept. of Mechanical and Industrial Engineering, Final Report No. A286683, Jan 2001.

[2] Gupta, A.K., Lilly, D.G., and Syred, N., "Swirl Flow", Abacus press, Kent, (1984).

[3] El-Banhawy, Y., and Whitelaw, J.H., Combustion and Flame, Vol.54, pp: 253-275, (1981).

[4] Syred, N., and Beer, J.M., "Combustion in Swirling Flow: A Review," Combustion and Flame, 23 :143-201, 1974

[5] Lilley, D.G., "Swirling Flows in Combustion : A Review," AIAA, 15: 1603-1078, 1977.

[6] Faeth, G.M., Progress in Energy and Combustion Science, Vol.9, pp: 1-76 (1983).

[7] Smoot, L.D., and Hill, S.C., Progress in Energy and Combustion Science, Vol.9, pp: 77-103 (1983)

[8] Law, C.K., Progress in Energy and Combustion Science, Vol.8, pp: 169-199 (1982).

[9] William, A.K., Progress in Energy and Combustion Science, Vol.2, pp: 167-179 (1976).

[10] Kevin M. Lyons, North Carolina state, Univ.atReleigh, Dept.of Mechanical and Aerospace Engineering, Final Report No. A904624, Aug.2004.

[11] Yule, A.J., AhSeeng, C., Felton, P.G., Urget,A., and Chigier, N.A., Combustion and Flame, Vol.44, pp: 71-84, (1982).

[12] Yule, A.J., Ereaut, P.R., and Urget, A., Combustion and Flame, Vol.54, pp: 15-22, (1983).

[13] Komiyama, K., Flagon, R.C., and Heywood, J.B., Sixteenth Symposium Institute, Int., on combustion, the Combustion Institute, Pittsburgh, pp: 549-560, (1977).

[14] Onuma, Y., Ogasawara, M., and Inoue, T., Sixteenth Symposium Institute, Int., on combustion, the Combustion Institute, Pittsburgh,pp:561-567,(1977).

[15] Presser, C., Gupta, A.K., and Semerjian, H.G., Combustion and Flame, Vol.92, pp: 25-44, (1993).

[16] Toshimi Takagi, Hyun Dong Shin and Akra Ishio, Combustion and Flame, Vol.41, pp: 261271 (1981).

[17] Mercier X.,Therssen E., Pauwels J.F., and Desgroux P., Combustion and Flame, Vol.125, pp: 656-667, (2001).

[18] Nayan Patel and Suresh Menon, Combustion and Flame, Vol.153, issue 2, pp: 228-257, April (2008). 
[19] Presser, C., Goldman, Y., Greeberg, J.B., and Timnat, Y.M., Proc. $18^{\text {th }}$ (Int.) Symp. On Combustion, pp:1939-1948, (1981).

[20] Chigier, N.A., Combustion Science and technology, vol.3, No.1,pp:31-37, (1965).

[21] Moneib, H.A., Ismail, M.A., and Hussien, A.M.M., Proceeding of $7^{\text {Th }}$. Int.Conf. of Mech.Power Eng.,Vol. 1,II-18, Cairo, December, pp: 17-20, (1990).

[22] Iyengar, V., Simmons, H., Ranson, D. and Halzschuh, T., ASME, GT22375, Glasgow, 2010

[23] Owen, F.K., Spadaccini, I.J., Kennedy, J.B., and Bowman, C.T., Proc. $17^{\text {th }}$ Symp. (Int.) on Combustion (1978).

[24]El-Banhawy, Y.H., El-Ehwany, A.A., and Hagag, E.H., Proc. $7^{\text {th }}$ Conference (Int.) of Mech. Power Eng., Vol.1, pp:II/(21-1)-(21-14), (1990).

[25]El-Mahallawy, F.M., Khalil, E.E., and Abdelal, O., The Fourth (Int.) Conference for Mech. Power Eng., Cairo, (1982).

[26] Abd El-Samed, A.K., Engineering Research Journal, ERJ, Faculty of Engineering, Minoufiya University, Vol.32, No.4, pp:499509, October 2009.
[27]Han Y.M., Seol W.S., Lee D.S., Yagodkin V.I., and Jeung I.S., J. Engineering for Gas Turbines and Power, January, vol.123, pp: 3340, (2001).

[28] Yei-Chin Chao, Yong-Li Chang, Chih-Yung $\mathrm{Wu}$, and Tsarng-Sheng Cheng, Symposium (International) on Combustion, Vol.28, issue 1, pp:335-342, (2000).

[29] Wang,H.Y., Bechtold,J.K., and Law,C.K., Combustion and Flame, Vol.145, issue 2, pp: 376-389, April (2006).

[30]Chin-Yung Wu, Yei-Chin Chao, Tsamg-Sheng Cheng, Yueh-Heng Li, Kuo-Yuan Lee, and Tony Yuan, "The Blowout Mechanism Of Turbulent Jet Diffussion Flames", Combustion and Flame, Vol.145, issue 3, pp: 481-494, May (2006)

[31] Beèr, J.M., and Chigier, N.A., "Combustion Aerodynamics”, Applied Science, London, (1972)

[32] Abd El-Samed, A.K., Port-Said Engineering Research Journal, Vol.6, No.1, pp:100-119, (2002).

[33] Tharwat, M.F., Shaaban, M.M., and AbelMageed, S.I., $7^{\text {th }}$ (Int.) Conference of Mech. Power Engineering, Cairo, Egypt, (1990). 


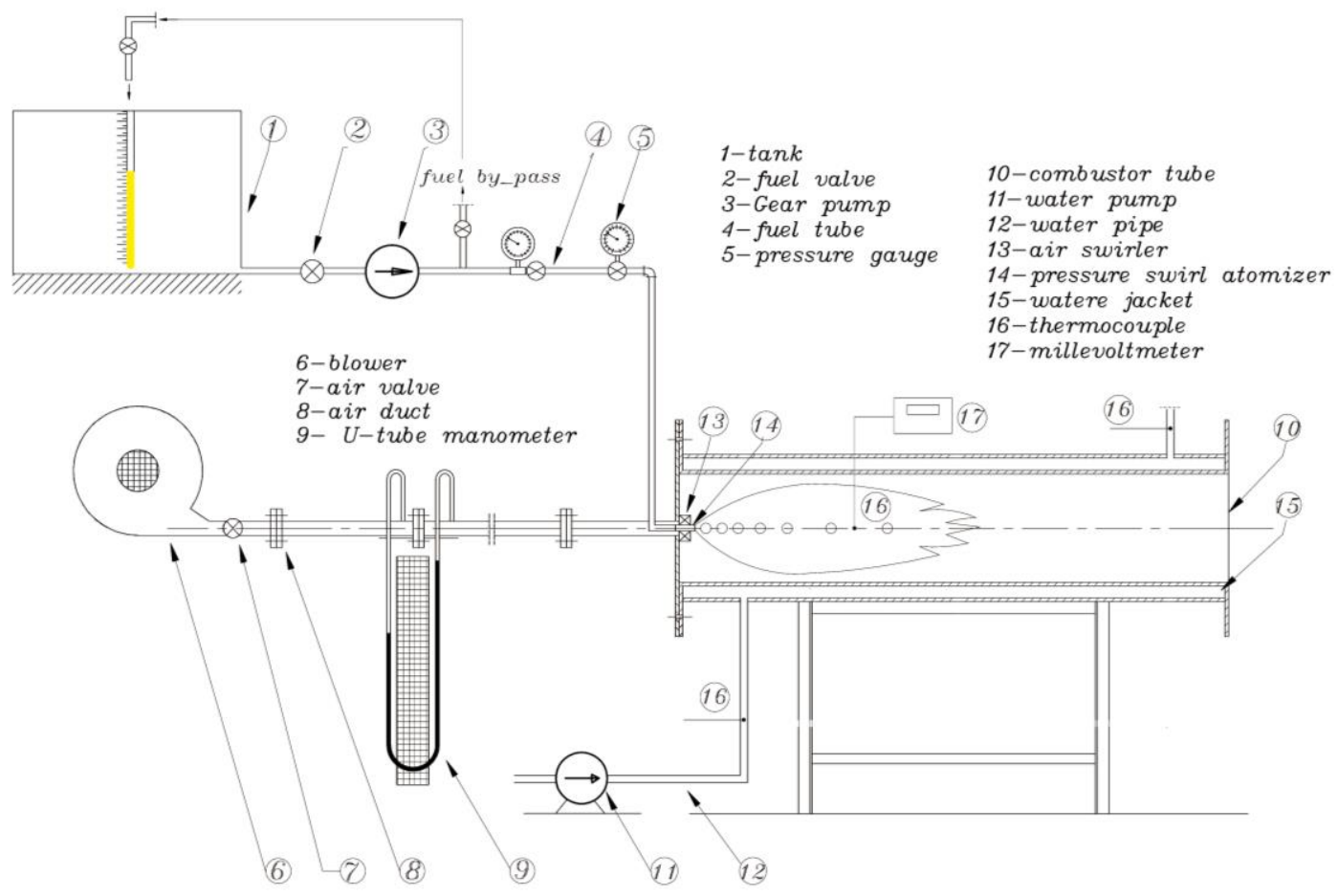

Fig. 1 Schematic Diagram of the Experimental Apparatus

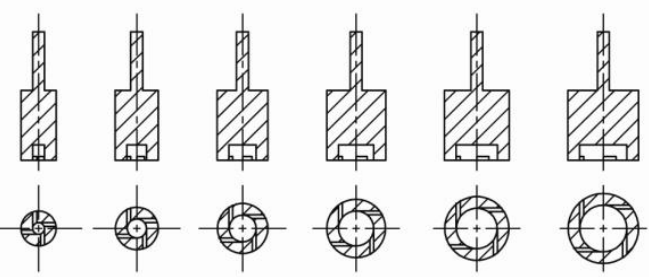

Group A-1 $D_{s}=3,5,7,9,10.5,12 \mathrm{~mm}$

Fig. $2 a$

Geometrical

Design
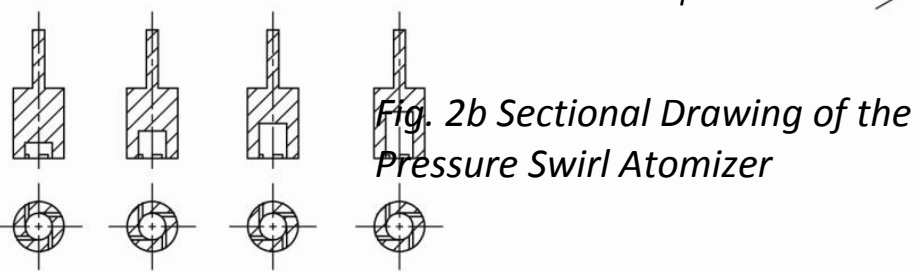

Parameter of

the Fuel Spin

Chamber

Group A-2 $L_{s}=4,7,9.3,12 \mathrm{~mm}$



Group B-2 $d_{h}=34,40,46,51,57,62 \mathrm{~mm}$

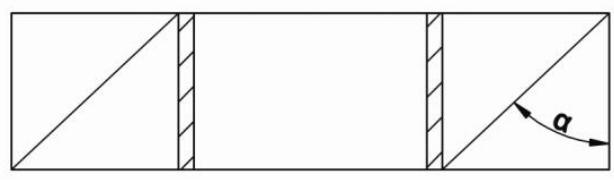

Group B-1 $\alpha=30^{\circ}, 45^{\circ}, 60^{\circ}$

Fig. 3 Geometrical Design Parameter of Combustion Air Swirler 


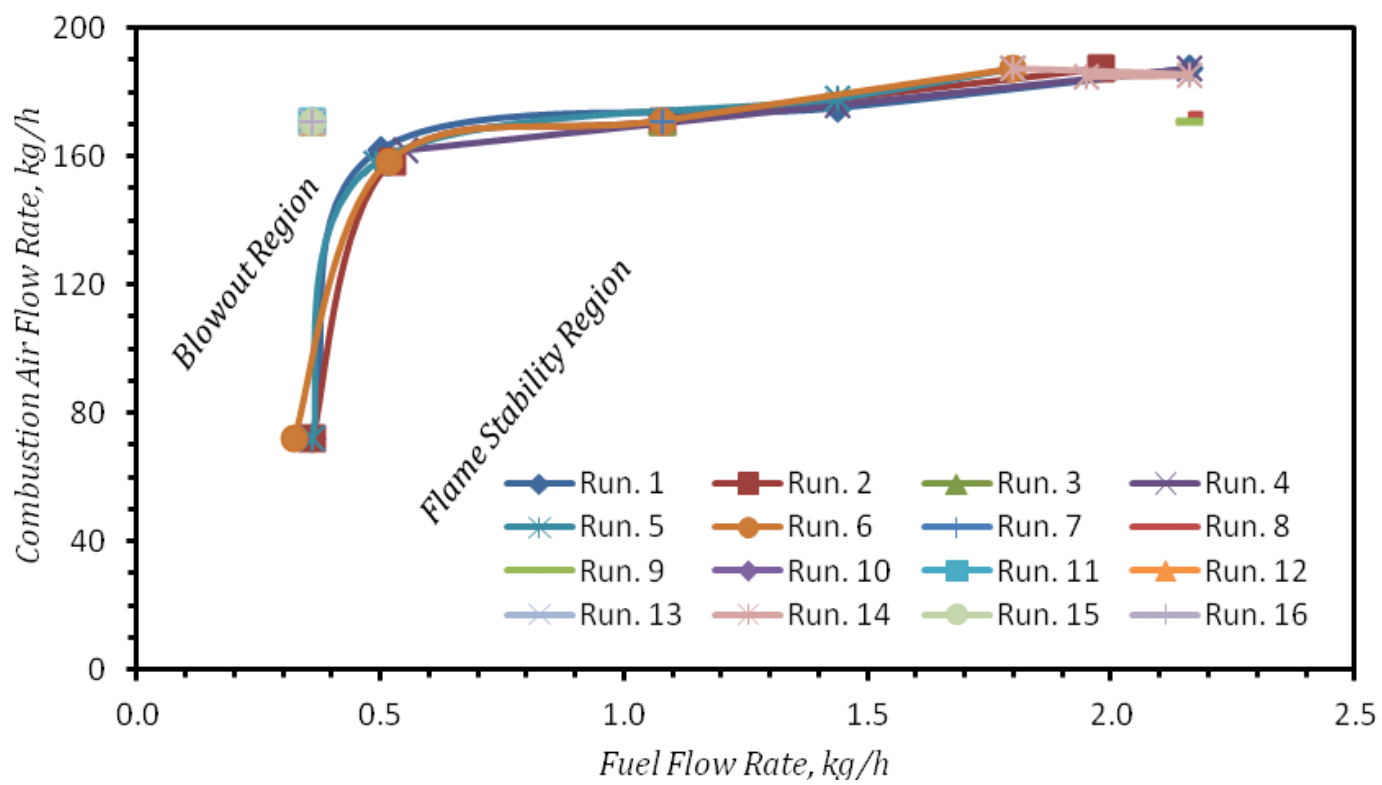

Fig. 4 Lean Blowouts and Flame Stability Limits (16 Runs)



Run 1 (98 )

Diameter $=3 \mathrm{~mm}$

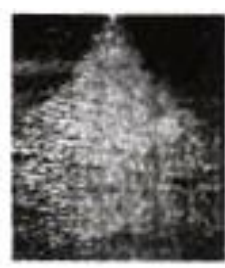

Run $2\left(75^{\circ}\right)$

Diameter $=5 \mathrm{~mm}$

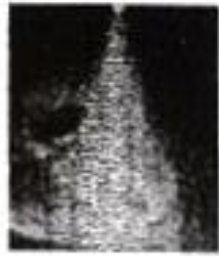

Run $3\left(36^{\circ}\right)$

Diameter $=7 \mathrm{~mm}$

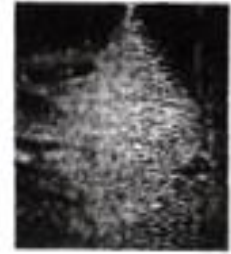

Run $4\left(62^{\circ}\right)$

Diameter $=9 \mathrm{~mm}$

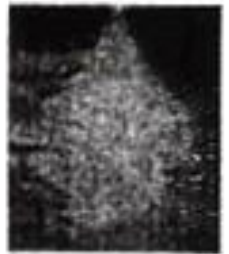

Run $5\left(66^{\circ}\right)$

Diameter $=10.5 \mathrm{~mm}$



Run $6\left(75^{\circ}\right)$

Diameter $=12 \mathrm{~mm}$

Fig. 5 Photographers shows the Effect of Changing Fuel Spin Chamber Diameter on the Measured Spray Cone Angles. (With Constant Fuel Spin Chamber Depth $=4 \mathrm{~mm}$ )



Fig. 6 Effect of Changing Spin Chamber Diameter on the Value of the Measured Spray Cone Angles and on the Confined Flame Length (with Constant Spin Chamber Depth $=4 \mathrm{~mm}$ ). 




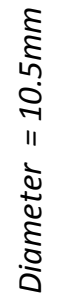

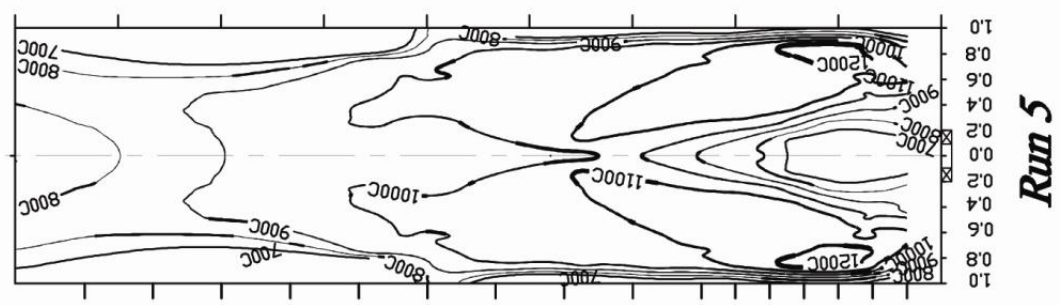

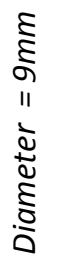

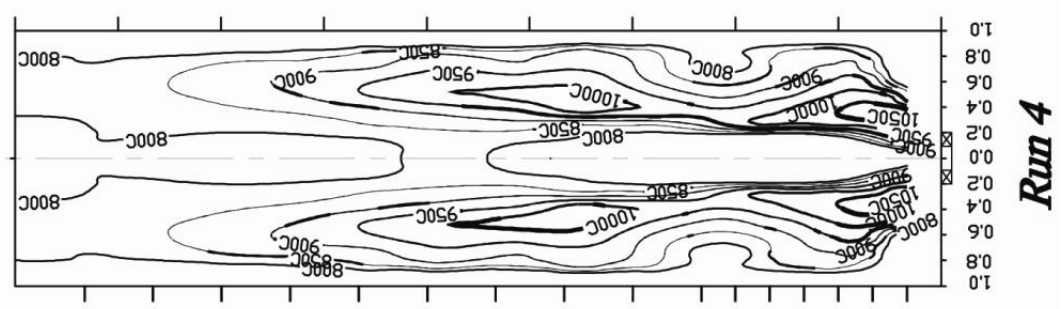

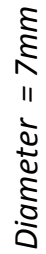



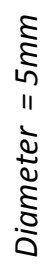

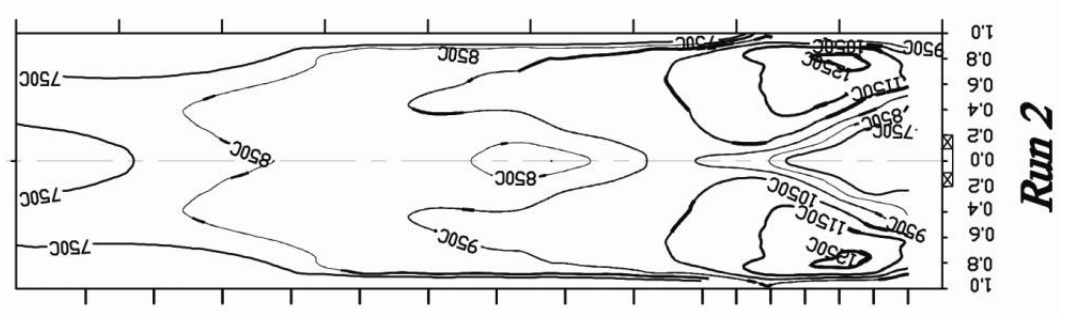

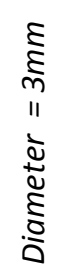






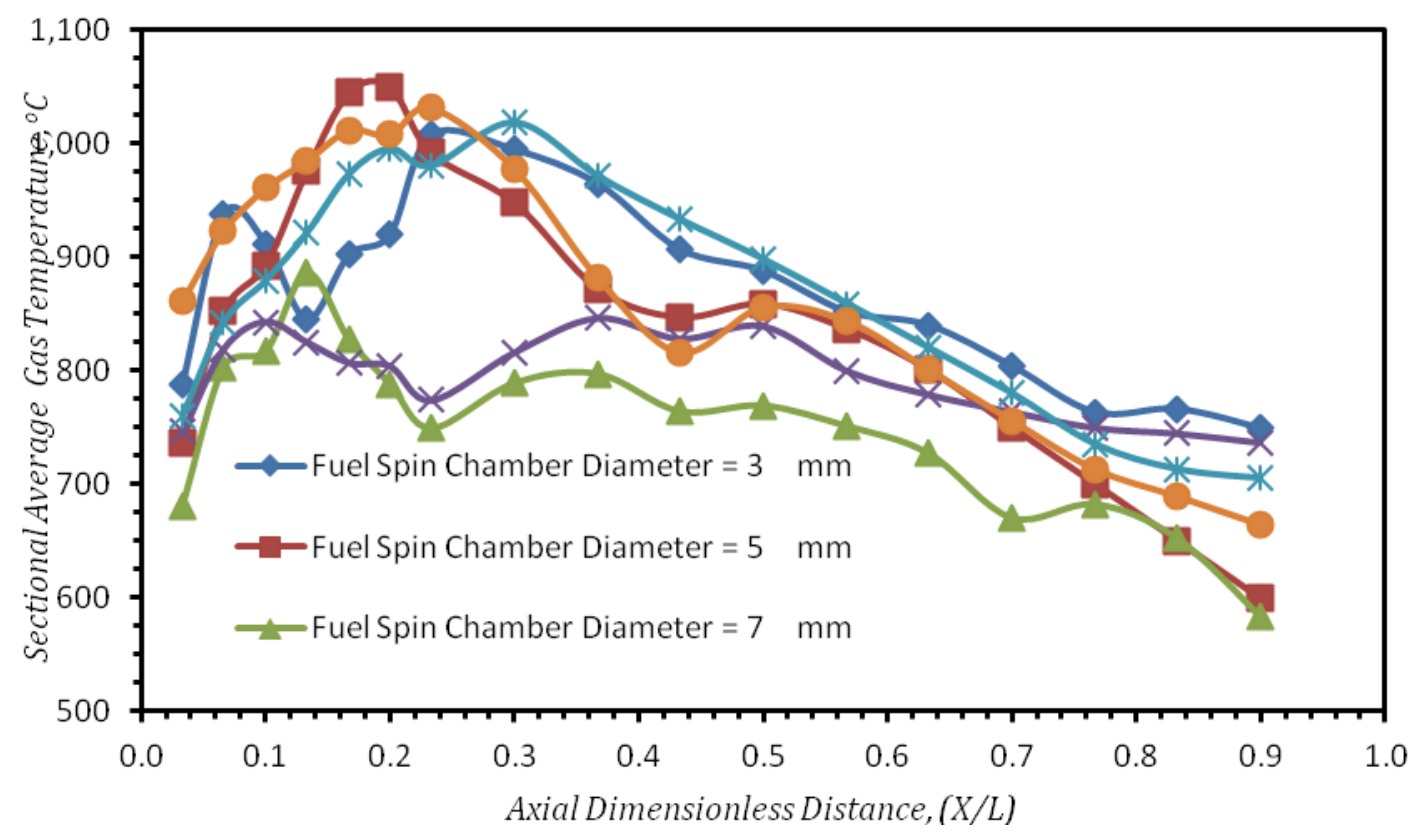

Fig. 8 Effect of Changing Fuel Spin Chamber Diameter on the Sectional Average Gas Temperature along the Combustor Center Line

(With Constant Spin Chamber Depth $=4 \mathrm{~mm}$ ).

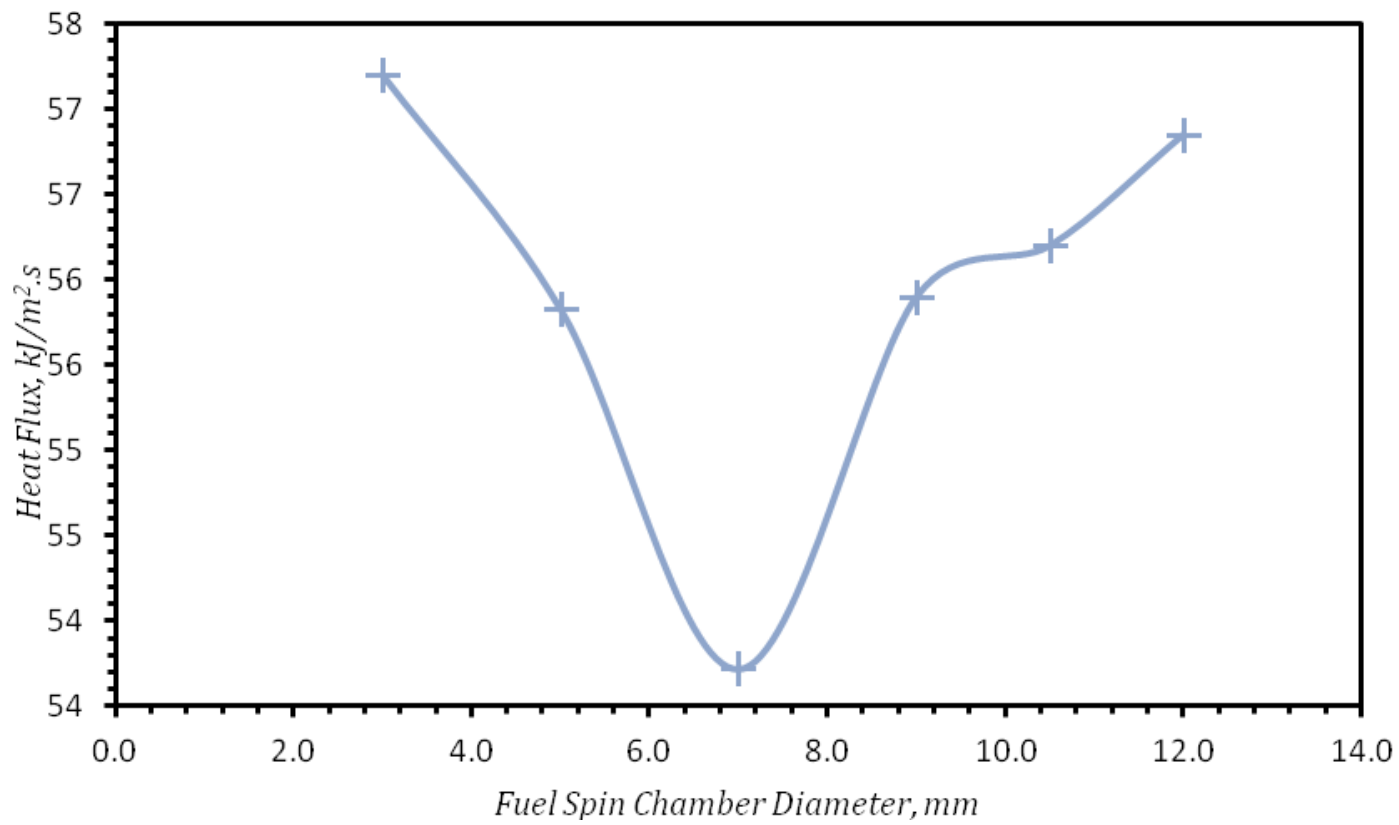

Fig. 9 Effect of Changing Fuel Spin Chamber Diameter on the Overall Heat Transfer to the Combustor Wall

(With Constant Fuel Spin Chamber Depth $=4 \mathrm{~mm}$ ). 


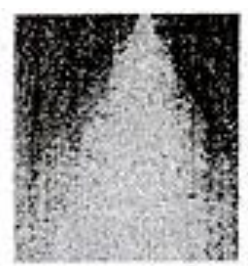

Run $3\left(36^{\circ}\right)$

Depth $=4 \mathrm{~mm}$



Run $7\left(64^{\circ}\right)$

Depth $=7 \mathrm{~mm}$



Run $8\left(76^{\circ}\right)$

Depth $=9.3 \mathrm{~m}$

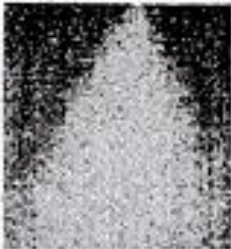

Run $9\left(54^{\circ}\right)$

Depth $=12 \mathrm{~mm}$

Fig. 10 Photographs Shows the Effect of Changing Fuel Spin Chamber Depth on the Measured Spray Cone Angles.

(With Constant Fuel Spin Chamber Diameter $=7 \mathrm{~mm}$ )



Fig. 11 Effect of Changing Fuel Spin Chamber Depth on the Measured Spray Cone Angles and on the Confined Flame Length

(With Constant Fuel Spin Chamber Diameter $=7 \mathrm{~mm}$ ) 


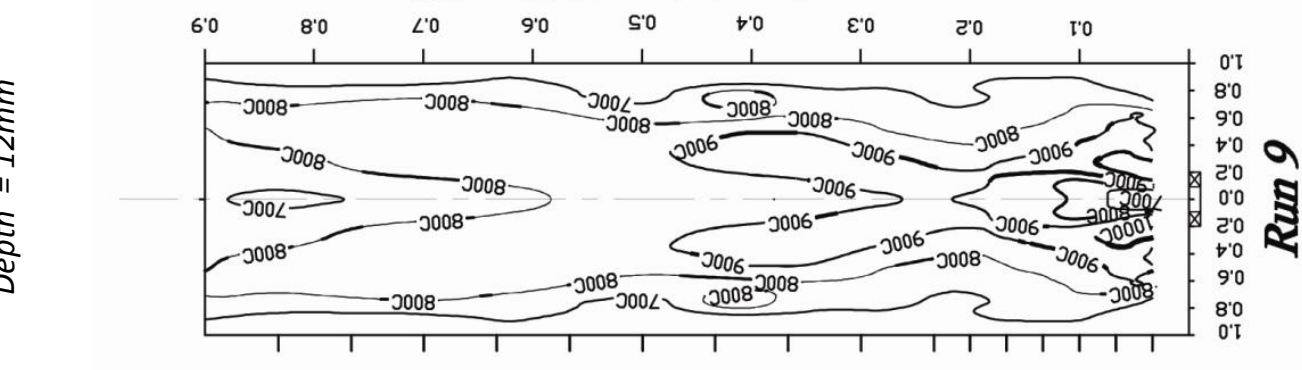

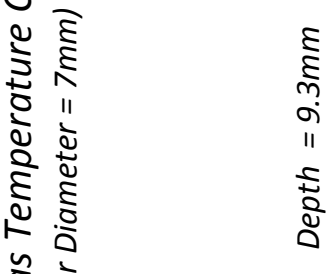

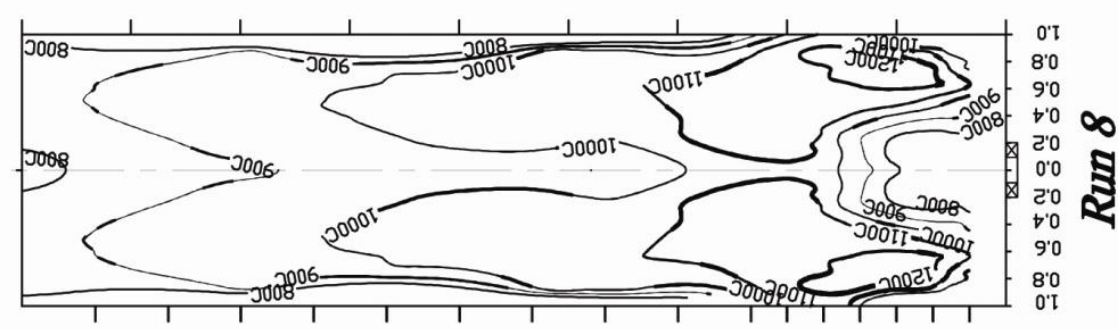

ஸั

$\frac{\text { वे }}{\sum^{2}}$

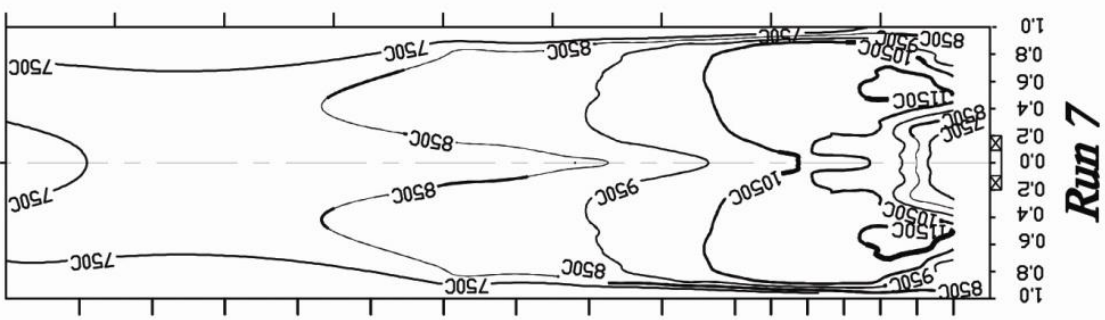



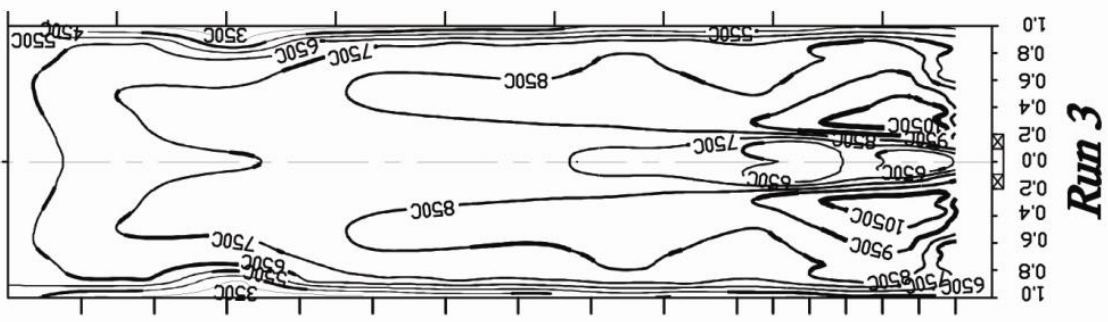




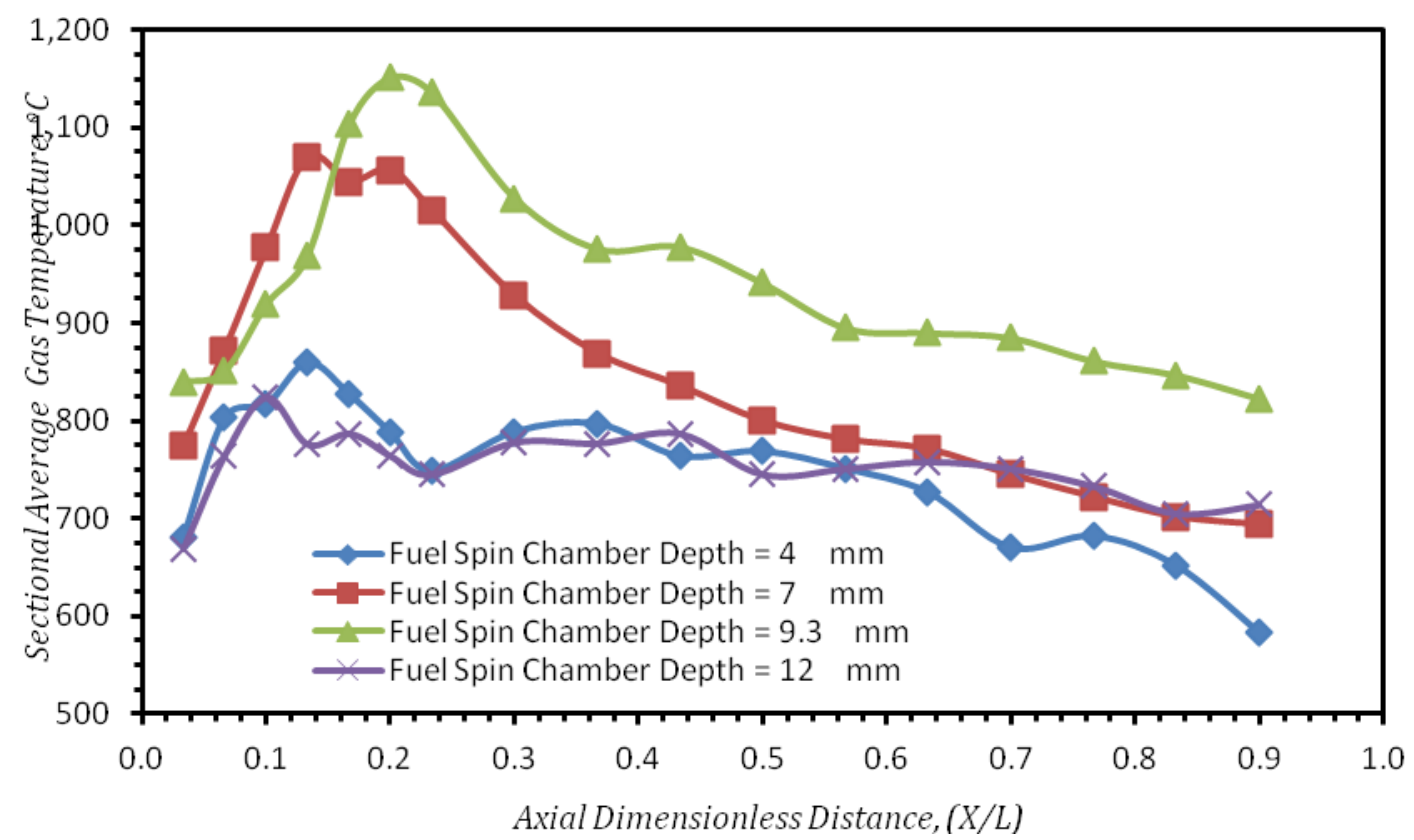

Fig. 13 Effect of Changing Fuel Spin Chamber Depth on the Sectional Average Gas Temperature along the Combustor Center Line

(With Constant Fuel Spin Chamber Diameter $=7 \mathrm{~mm}$ ).

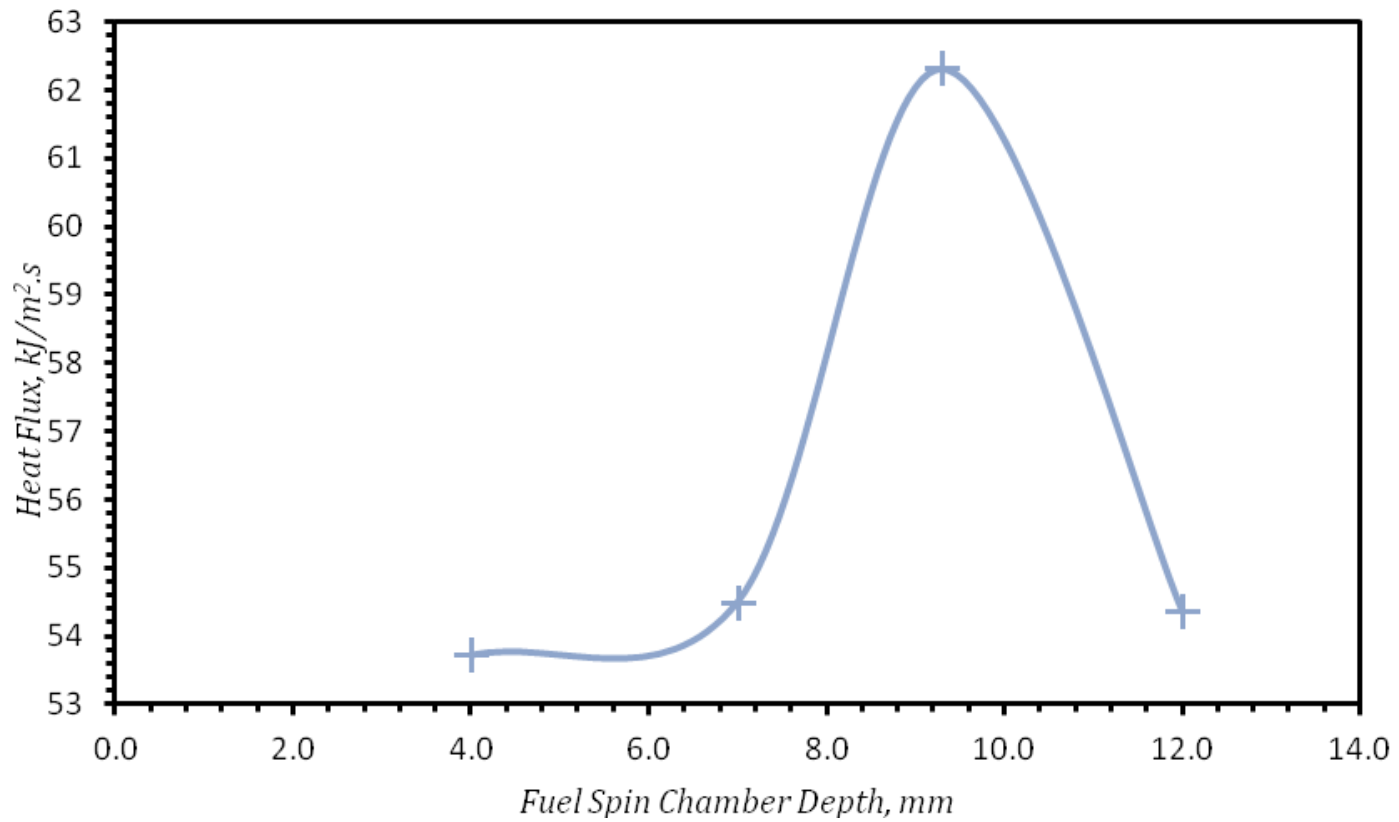

Fig. 14 Effect of Changing Fuel Spin Chamber Depth on the Overall Heat Transfer to the Combustor Wall

(With Constant Fuel Spin Chamber Diameter $=7 \mathrm{~mm}$ ) 


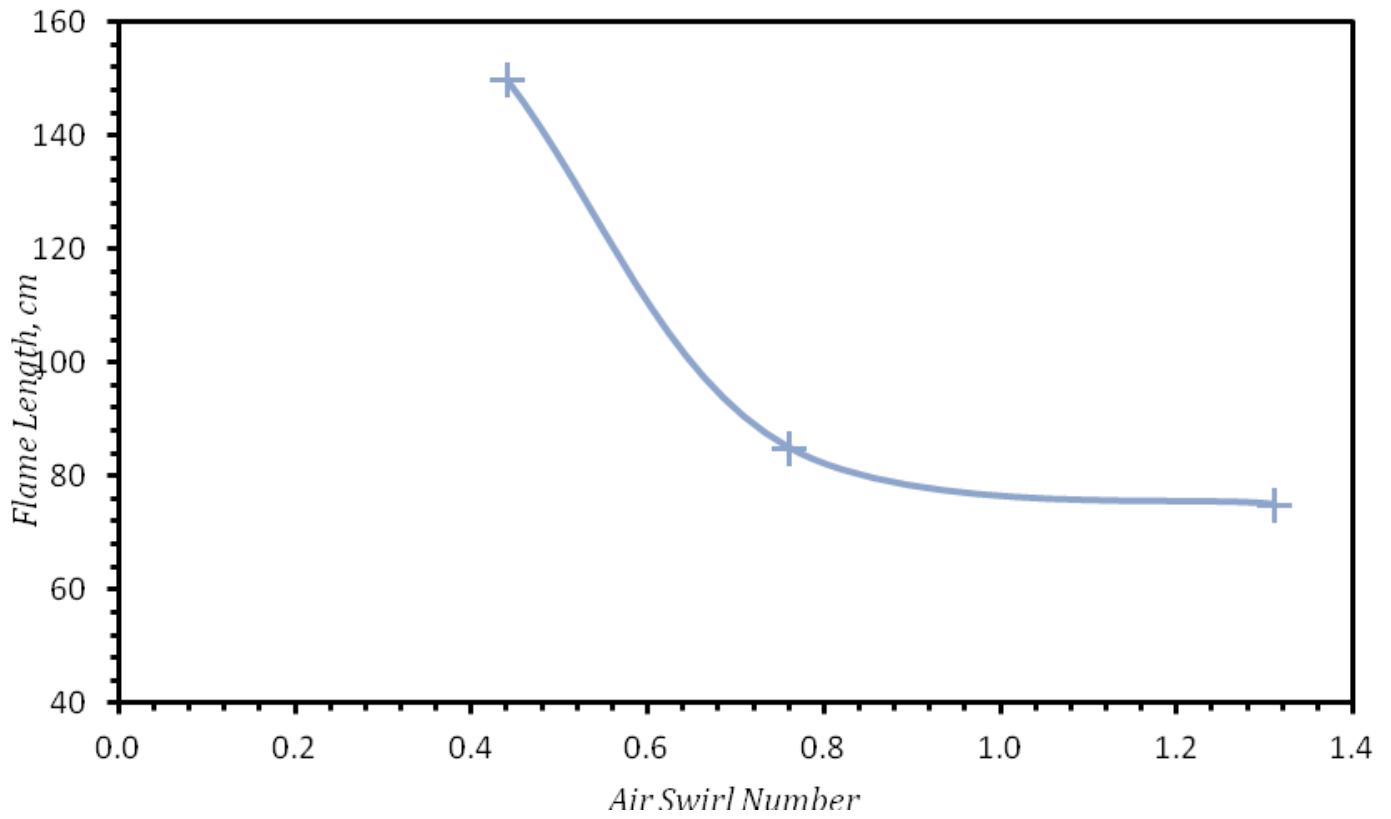

Fig. 15 Effect of Changing Air Swirler Number on the Confined Flame Length (With Fuel Spin Chamber Diameter and Depth $=7 \mathrm{~mm}, 4 \mathrm{~mm}$ ).



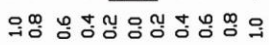

Run 3

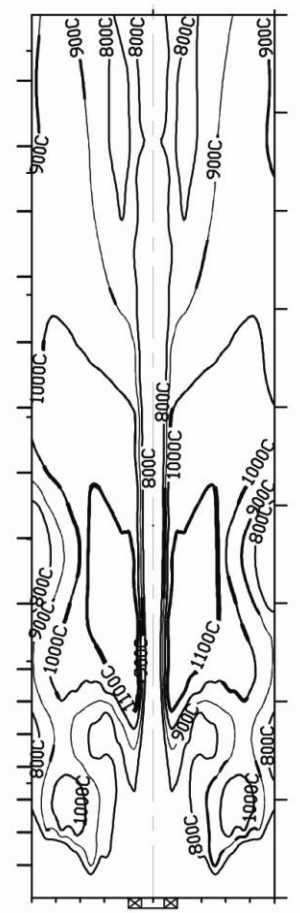


Run 15

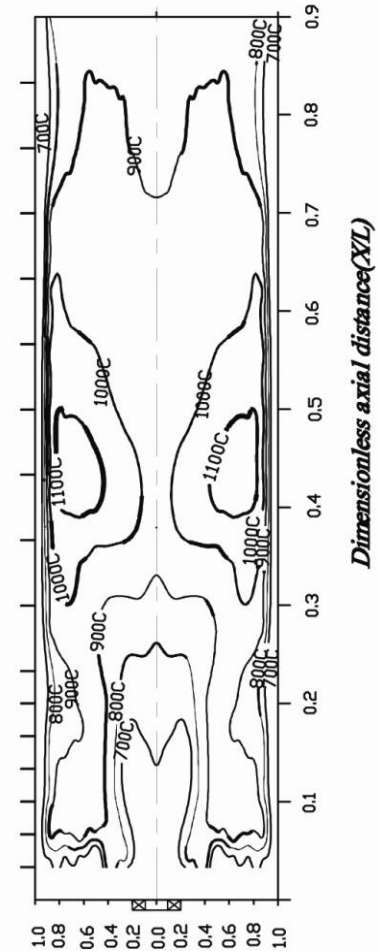

Run 16

$S N=1.31$

$S N=0.76$

$S N=0.44$

Fig. 16 Effect of Changing Air Swirl Number on Gas Temperature Contours along the Combustor (With Constant Fuel Spin Chamber Diameter, Depth $=7 \mathrm{~mm}, 4 \mathrm{~mm}$ ) 


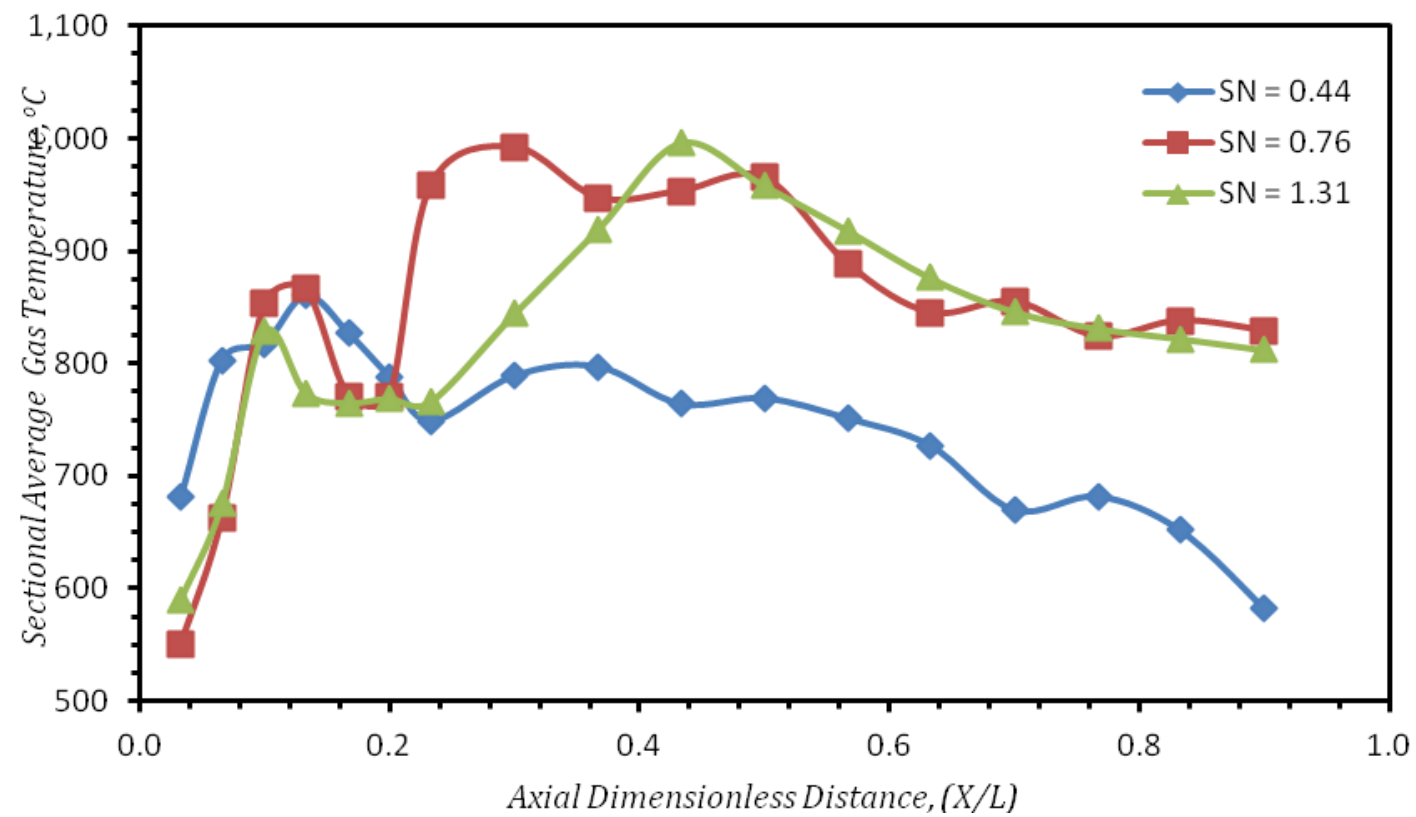

Fig. 17 Effect of Changing Air Swirl Number on the Sectional Average Gas Temperature along the Combustor Center Line

(With Fuel Spin Chamber Diameter and Depth $=7 \mathrm{~mm}, 4 \mathrm{~mm}$ ).

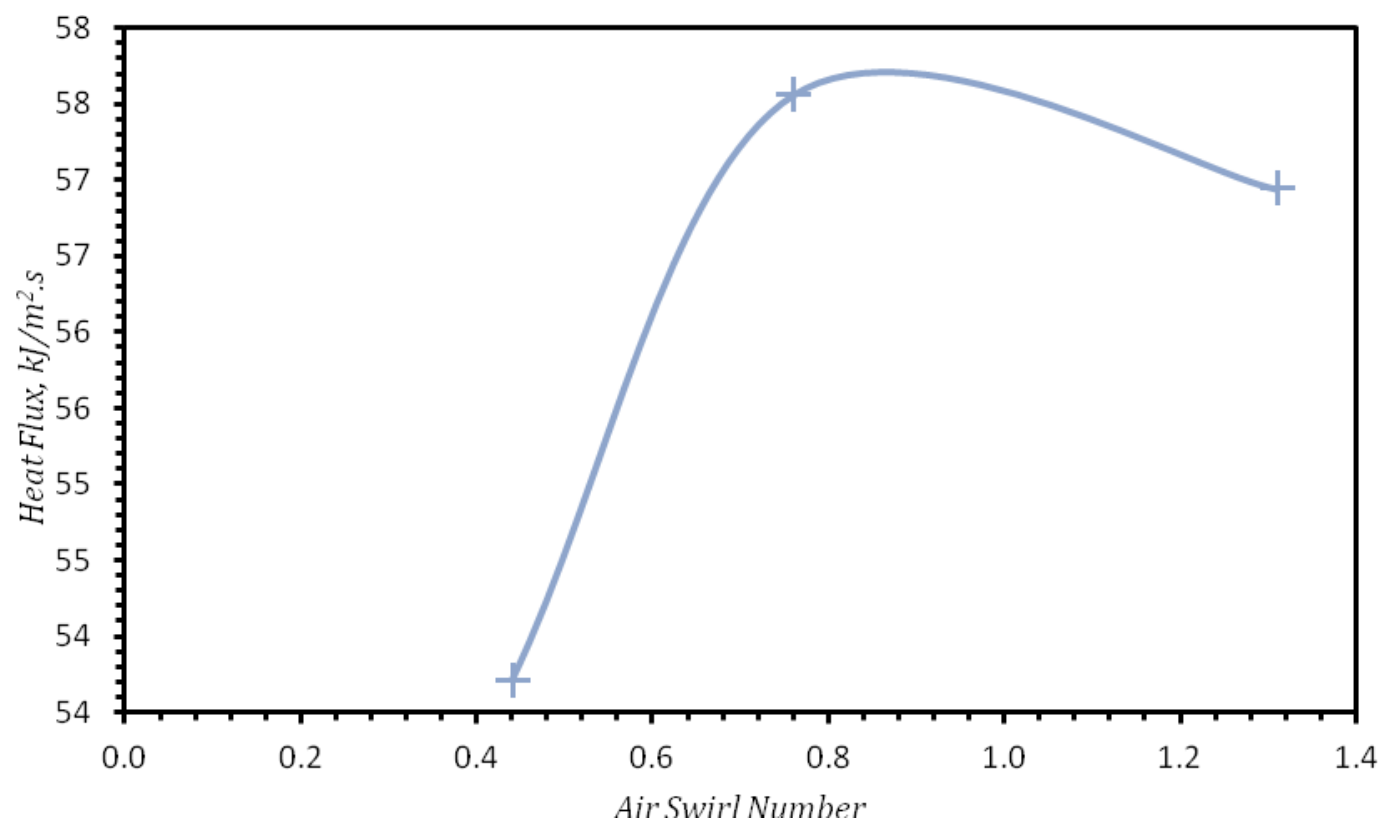

Fig. 18 Effect of Changing Air Swirl Number on the Overall Heat Transfer to the Combustor Wall (With Fuel Spin Chamber Diameter and Depth $=7 \mathrm{~mm}, 4 \mathrm{~mm}$ ). 


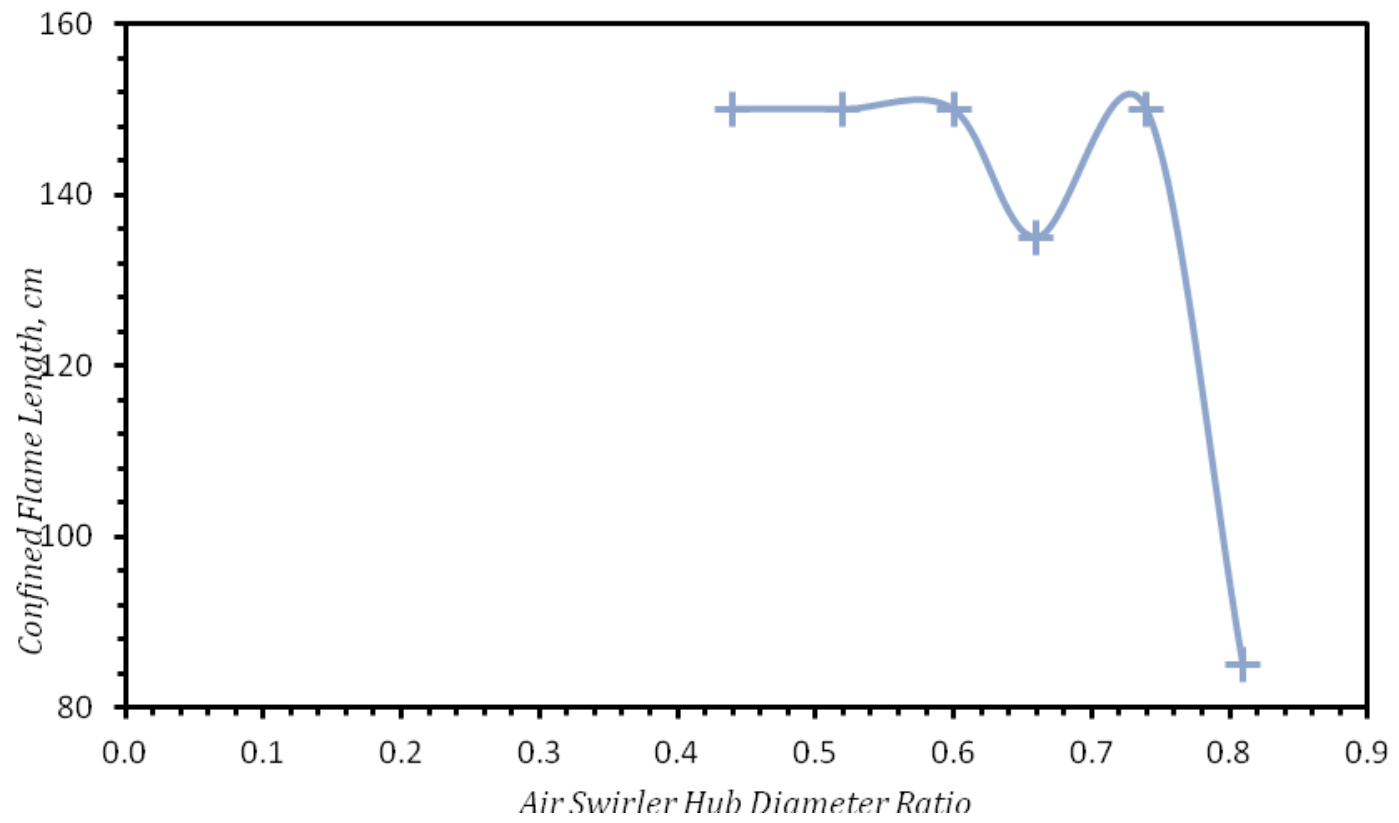

Fig. 19 Effect of Changing Air Swirler Hub Diameter on the Confined Flame Length (With Fuel Spin Chamber Diameter and Depth $=7 \mathrm{~mm}, 4 \mathrm{~mm}$ ). 


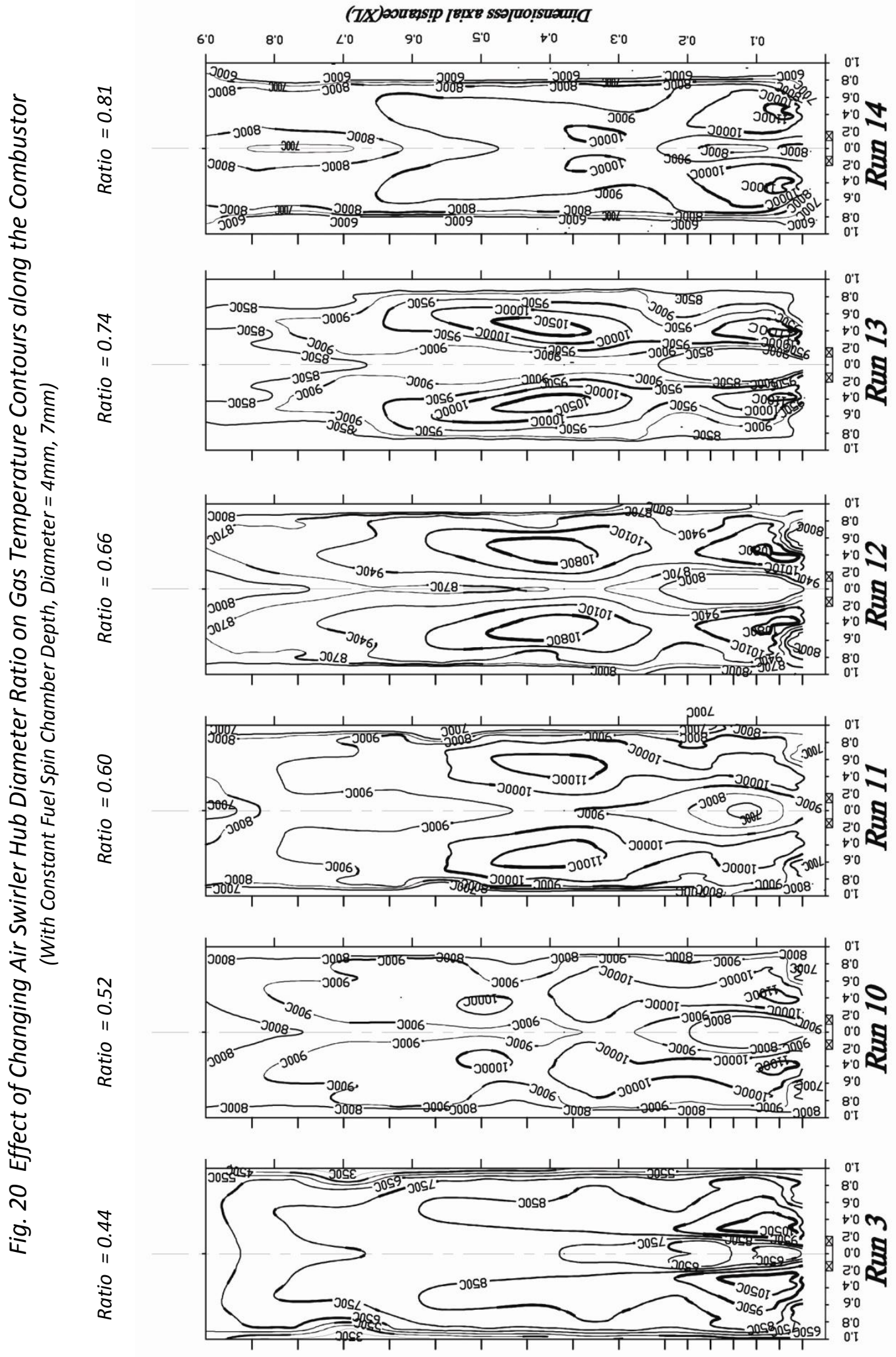




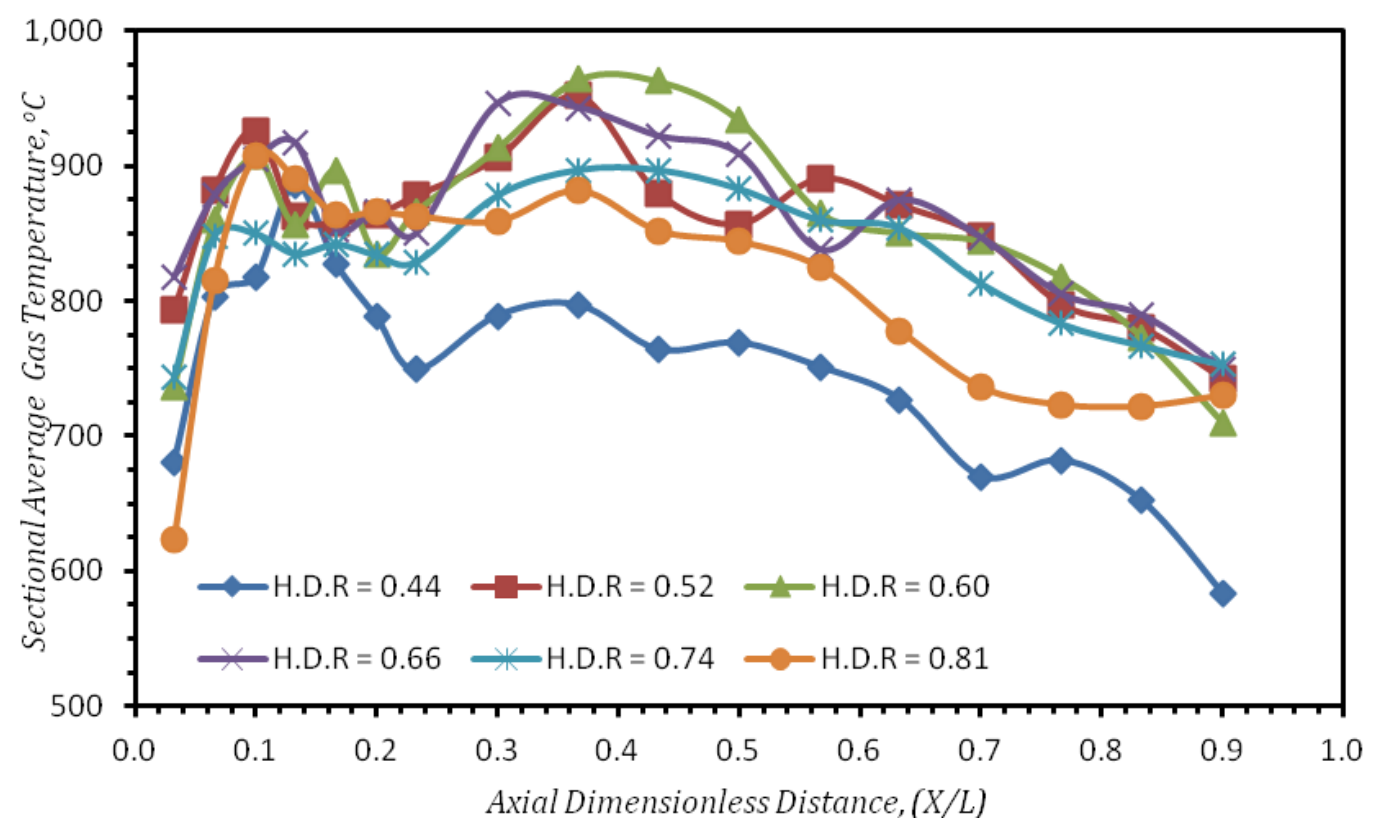

Fig. 21 Effect of Changing Air Swirler Hub Diameter Ratio on the Sectional Average Gas Temperature along the Combustor Center Line (With Fuel Spin Chamber Diameter and Depth $=7 \mathrm{~mm}, 4 \mathrm{~mm}$ ).



Fig. 22 Effect of Changing Air Swirler Hub Diameter Ratio on the Overall Heat Transfer to the Combustor Wall

(With Fuel Spin Chamber Diameter and Depth $=7 \mathrm{~mm}, 4 \mathrm{~mm}$ ). 